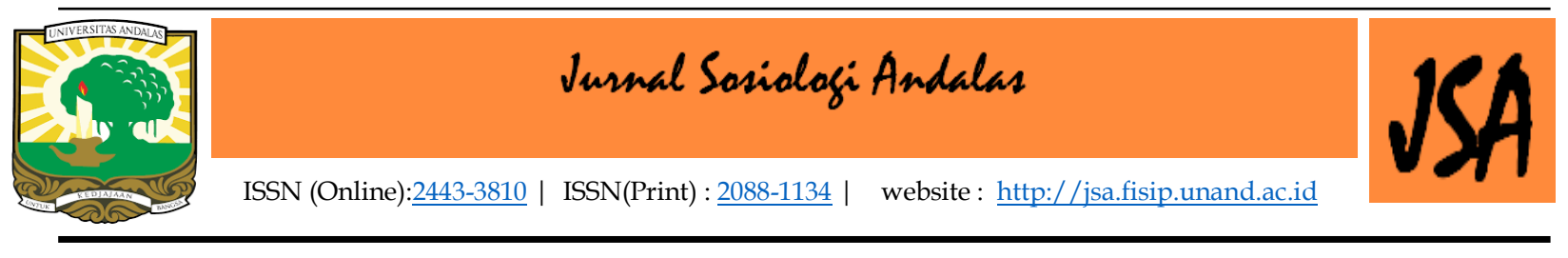

\title{
Strategi Peer Educator untuk Peningkatan Kesadaran Pekerja Seks Perempuan terhadap Kesehatan Reproduksi
}

\author{
Lidya Febrina \\ Jurusan Sosiologi, FISIP Universitas Andalas \\ Email: lidya.febrina03@gmail.com
}

\begin{abstract}
Abstrak: This article presents the results of research on peer educator strategies to raise female sex workers' awareness of reproductive health. The objectives of this study were 1) to describe the strategies used by peer educators to build sex worker awareness of workers' reproductive health; 2) Identifying barriers to peer educators in providing education on reproductive health to female sex workers. To achieve the research objectives, the theory used is the Social Exchange Theory of George C, Homans and the research approach used is qualitative with descriptive research type. To obtain data, researchers used in-depth interviews and observation techniques. The results showe that the strategies used by peer educators in providing education about reproductive health were: coercion, giving advice, and persuasion. Meanwhile, the obstacles found by peer educators in providing education on reproductive health were: the imbalance of exchanges between peer educators and female sex workers and the distrust of female sex workers in peer educators.
\end{abstract}

Keywords: Empowerment strategies, Peer Educator, Female Sex Workers, Reproductive Health, HIV/AIDS

\section{A.PENDAHULUAN}

Pada saat ini, kehidupan wanita tuna susila atau yang akhir-akhir ini disebut Pekerja Seks Komersial (PSK) merupakan fenomena yang tidak asing lagi dalam kehidupan masyarakat. PSK merupakan seseorang yang melakukan hubungan seksual dengan lawan jenisnya secara berulang-ulang, di luar perkawinan yang sah dan mendapat uang, materi atau jasa (Simajuntak, 1982:25).

PSK sebenarnya telah muncul jauh sebelum peradaban modern menyentuh masyarakat, karena sejak dahulu kala telah ditemukan prostitusi atau pelacuran ini, contohnya zaman Nabi Muhammmad SAW sekalipun prostitusi telah ada dan menjadi suatu permasalahan yang ada pada saat itu menjadi gambaran masyarakat pada zaman tersebut (Ardila, 2016:2).

Riset lembaga peneliti aktivitas pasar gelap, menghimpun data negara-negara paling banyak belanja prostitusi dengan menggunakan data dari program kesehatan masyarakat, penegak hukum \& media menemukan bahwa PSK terbanyak di Dunia ada pada benua Asia yaitu China dengan total pembelanjaan prostitusi 73 miliar/tahun dan Indonesia menempati urutan ke 12 dengan total pembelanjaan 2,25 miliar/tahun (Lasyera, 2018:2). 
Di Indonesia lokasi transaksi seks terdapat hampir di setiap kabupaten/kota, salah satunya di kota Padang. Jumlah PSK di Kota Padang semakin meningkat dan tempat praktiknya semakin berkembang. Lokasinya seperti di salon, panti pijat, objek wisata yang sepi, tempat karaoke, kafetaria dan sejenisnya, tempat pribadi seperti rumah/pondok yang disiapkan oleh oknum masyarakat, warung remangremang bahkan sampai ada yang melakukan pekerjaan tersebut di atas roda empat (Lasyera, 2018:5).

Seks komersial ditandai dengan perilaku seks yang berisiko secara bergontiganti pasangan, rendahnya penggunaan kondom pada transaksi seks, akses pada layanan kesehatan yang masih terbatas dan PSK bekerja dalam berbagai macam bentuk (Haryanti, 2014). Aktivitas seks komersial yang demikian cenderung rentan terkena penyakit menular seks antara lain HIV/AIDS. Penyakit ini menjadi ancaman di seluruh dunia tanpa terkecuali Indonesia, karena belum ditemukannya obat atau vaksin yang efektif, sedangkan penyebaran penyakit ini terus berlanjut (Lestari, 2015:143).

Berdasarkan data dari UNAIDS, terdapat 36,9 juta masyarakat dari berbagai negara hidup bersama HIV/AIDS pada 2017. Penderita HIV/AIDS lebih banyak diderita oleh kaum wanita, yakni sebanyak 18,2 juta penderita. Penderita HIV terbanyak terdapat di Kawasan Afrika Timur dan Selatan dengan angka mencapai 19,6 juta penderita. Indonesia sendiri jumlah penderita HIV sebanyak 620.000 jiwa yang tersebar di berbagai provinsi di Indonesia. Pada tahun 2018 di Sumatera Barat sendiri terdapat 1.860 orang yang terkena HIV / AIDS (Gosumbar.com diakses pada, 20 Juli 2019).

Bentuk perhatian Dunia terhadap penularan HIV/AIDS salah satunya dengan diselenggarakannya International Conference of Population and Development (ICPD) di Kairo tahun 1994, yang merupakan salah satu tonggak sejarah bagi perempuan. Hal ini dikarenakan Konferensi inilah salah satu yang pertama kali menetapkan "kesehatan seksual/reproduksi" sebagai sebuah hak yang komprehensif. Setiap orang harus mendapatkan pelayanan kesehatan reproduksi yang memadai. Maka bila ada golongan tertentu (anak/remaja) yang karena sebab-sebab tertentu tidak dapat mengakses pelayanan, maka hal tersebut termasuk pelanggaran hak .

Upaya penanggulangan HIV/AIDS salah satunya dilakukan dengan membentuk United Nations Fund Population Activies (UNFPA), merupakan badan yang mendukung program di empat wilayah, yaitu negara Arab dan Eropa, Asia dan Pasifik, Latin dan Karibia, serta Afrika sub-Sahara. Dalam Bahasa Indonesia disebut Dana Penduduk Perserikatan Bangsa-bangsa.

Tugas UNFPA melibatkan penyediaan suplai dan layanan untuk merawat kesehatan. Mereka juga mendorong partisipasi pemuda dan wanita untuk membantu mengembangkan masyarakat yang terkena dampak kesehatan buruk yang meluas ke berbagai sektor, seperti pencegahan penyakit kelamin, termasuk HIV/AIDS (Francesco-toldo.net diakses pada 20 Januari 2019).

Melalui kerja sama dengan UNFPA, Kementerian Kesehatan Republik Indonesia membentuk Program Pencegahan HIV/AIDS untuk Pekerja Seks Perempuan. Kementerian Kesehatan Republik Indonesia memberi peluang kepada berbagai organisasi masyarakat untuk melaksanakan program tersebut, dengan mengajukan proposal dan harus memenuhi beberapa syarat tertentu. Salah satu 
organisasi masyarakat yang dipercaya menjalankan program ini adalah Perkumpulan Keluarga Berencana Indonesia (PKBI).

Pemberdayaan yang dilakukan oleh PKBI tersebut menurut pandangan sosiologis sangat tepat karena teman sebaya (Peer) adalah orang yang berada di lingkungan PSP itu sendiri yang akan dididik teman sebaya lainnya yang belum mendapatkan pelatihan atau penjangkauan. Peer educator dianggap berhasil melakukan pemberdayaan jika mereka mampu mengajak PSP untuk melakukan VCT (voluntary counselling and testing). Tes ini bertujuan untuk membantu pencegahan, perawatan, serta pengobatan bagi penderita HIV/ AIDS.

Saat ini jumlah peer educator yang dimiliki PKBI ada 31 orang yang masih aktif dalam melakukan penjangkauan. Peer educator ini terdiri dari PSP itu sendiri baik yang masih aktif, yang pasif maupun mantan PSP, serta mereka yang bukan PSP namun dekat dengan para PSP tersebut. Setiap peer educator memiliki strategi yang berbeda-beda dalam memberikan edukasi kepada pekerja seks perempuan tentang $\mathrm{HIV} / \mathrm{AIDS}$.

Peer educator dalam melaksanakan program ini masih menemui beberapa hambatan. Sehingga dengan adanya hambatan tersebut tidak semua tugas dan fungsinya sebagai peer educator dapat dilaksanakan dengan baik. Peer educator bertugas untuk memberikan edukasi mengenai HIV/AIDS, menjelaskan tentang bahaya serta proses penularan HIV, mengajak pekerja seks melakukan tes VCT, serta memberikan paket penjangkauan berupa kondom dan lubrikan apabila pekerja seks perempuan tersebut mau.

Namun tidak semua peer educator bisa mengajak pekerja seks untuk melakukan tes VCT. Beberapa diantara mereka hanya sebagai perantara sebagai akses masuk kepada pekerja seks itu saja, karena mereka mengenal pekerja seks tersebut, namun untuk mengajak pekerja seks melakukan tes VCT belum mampu mereka lakukan, hal ini dikarenakan latar belakang pekerjaan mereka yang berbeda dengan pekerja seks tersebut.

\section{Tinjauan Pustaka \\ Strategi}

Kata strategi adalah turunan dari kata bahasa Yunani, strategos. Adapun strategos dapat diterjemahkan sebagai komandan militer pada zaman demokrasi Athena. Secara bahasa, strategi dapat diartikan sebagai seni melaksanakan stratagem, yakni siasat atau rencana. Banyak pandangan strategi dalam bahasa inggris, dan yang dianggap relevan ialah kata approach (pendekatan) dan kata procedure (tahapan kegiatan). Dalam perspektif psikologi, kata strategi yang berasal dari bahasa Yunani itu, berarti rencana tindakan yang terdiri atas seperangkat langkah untuk mencapai tujuan.

Menurut Afif (dalam Megawati, 2006:9), strategi adalah upaya-upaya dan tindakan-tindakan penyesuaian untuk mengadakan reaksi terhadap situasi lingkungan tertentu dimana tindakan tersebut dilakukan secara sadar berdasarkan pertimbangan yang wajar. Dimensi strategi formal menurut Afif mengandung tiga unsur penting yakni: 
1. Tujuan atau sasaran yang paling penting untuk dicapai,

2. Kebijakan terpenting yang memberikan arahan dan batasan dalam bertindak,

3. Rangkaian tindakan dalam batas-batas yang telah ditetapkan.

Jadi strategi merupakan rencana atau siasat yang digunakan untuk mencapai suatu tujuan tertentu. Strategi juga diartikan sebagai sebagai upaya-upaya atau tindakan-tindakan penyesuaian untuk mengadakan reaksi terhadap situasi lingkungan tertentu, dimana tindakan itu dilakukan secara sadar dan berdasarkan pertimbangan yang wajar.

\section{Peer Educator}

Peer educator diartikan sebagai pendidik sebaya. Peer educator yaitu anak didik yang mempunyai pengaruh terhadap teman-temannya dan telah dilatih untuk melakukan pendampingan terhadap sesama anak didik bersama pekerja sosial. Sedangkan menurut United Nations Office on Drug and Crime (UNODC), peer educator adalah seseorang yang bekerjasama dengan mereka. Mereka yang mempunyai kesamaan umur, jenis kelamin, kelas sosial dan lainnya.

Menurut UNAIDS (dalam dalam Wahyuni, 2017:3) Pendidik sebaya adalah strategi dimana individu dari kelompok sasaran memberi informasi, pelatihan atau sumber daya untuk rekan-rekan mereka. Definisi peer educator menurut Youth Peer Education network (dalam Wahyuni, 2017) adalah suatu pendekatan dimana seseorang yang terlatih dan memiliki motivasi melakukan kegiatan informal dan terorganisir dengan rekan-rekan mereka yang memiliki kesamaan dengan diri mereka dalam usia, status sosial, ekonomi, dan latar belakang lainnya.

\section{Pekerja Seks Perempuan}

PSK merupakan seseorang yang melakukan hubungan seksual dengan lawan jenisnya secara berulang-ulang, di luar perkawinan yang sah dan mendapat uang, materi atau jasa (Simajuntak, 1982:25). Sedangkan menurut hukum yang berlaku Pekerja Seks Komersial (PSK) adalah pria atau wanita yang mengadakan hubungan kelamin dengan seorang lawan jenis di luar ikatan perkawinan yang sah dengan maksud mendapatkan kepuasan seksual atau keuntungan materi bagi diri sendiri ataupun orang lain (Pasal 1 Perda No 15 Thn 2002). Ada berbagai julukan yang diberikan pada profesi ini, antara lain pelacur, atau juga tunasusila. Akan tetapi, realitanya dalam penyebutan sehari-hari penyebutan PSK lebih populer, mudah dipahami dan terdengar lebih sopan dibandingkan julukan lainnya (Lestari , 2002:138).

\section{Kesehatan Reproduksi}

Kesehatan reproduksi menurut International Conference on Population and Development (ICDP) merupakan suatu keadaan sejahtera fisik, mental, dan sosial secara utuh, tidak semata-mata terbebas dari penyakit atau kecacatan dalam segala hal yang berkaitan dengan sistem, fungsi, dan proses reproduksi (Depkes, 2015) . Dengan demikian dapat disimpulkan bahwa setiap orang dapat menikmati kehidupan seks yang aman dan menyenangkan dan mereka memiliki kemampuan untuk bereproduksi, serta memiliki kebebasan untuk menetapkan kapan dan seberapa penting mereka ingin bereproduksi. Pelayanan reproduksi yang komprehensif adalah pelayanan reproduksi sepanjang siklus kehidupan manusia 
yang terdiri dari pelayanan kesehatan reproduksi esensial ditambah pelayanan reproduksi usia lanjut.

\section{Kerangka Teoretis}

Pada penelitian ini, peneliti menggunakan teori pertukaran sosial (exchange theory) yang dipelopori oleh George C. Homans. Teori pertukaran sosial itu dilandasi pada prinsip transaksi ekonomi yang elementer dalam artian pilihan rasional. Orang menyediakan barang atau jasa dan sebagai imbalannya berharap memperoleh barang atau jasa yang diinginkan. Ahli teori pertukaran mengasumsikan bahwa teori pertukaran mirip dengan transaksi ekonomi. Akan tetapi mereka mengakui bahwa pertukaran sosial tidak selalu diukur dengan nilai uang, sebab dalam berbagai transaksi sosial dipertukarkan juga hal-hal yang nyata dan tidak nyata (Poloma, 1994:52).

Menurut Homans, teori pertukaran dibangun atas dasar asumsi individualistik yang dipengaruhi oleh psikologi perilaku dan ilmu ekonomi elementer. Tujuan dasar dari perilaku manusia adalah tujuan ekonomis untuk memperbesar keuntungan, imbalan, dan ganjaran seluruh fenomena sosial. Substansi teori Homans terletak pada sekumpulan proposisi fundamental. Dari beberapa proposisi itu setidaknya menerangkan dua individu yang berinteraksi.

Teori pertukaran Homans bertumpu pada asumsi bahwa orang terlibat dalam perilaku untuk memperoleh ganjaran atau menghindari hukuman. Pertukaran perilaku untuk memperoleh ganjaran adalah prinsip dasar dalam transaksi ekonomi sederhana. Dalam proposisi Homans menyatakan bahwa bila seseorang berhasil memperoleh ganjaran atau menghindari hukuman, maka ia cenderung untuk mengulangi tindakan tersebut. Secara umum, dapat disimpulkan bahwa pada pokoknya teori Homans tidak mengakui bahwa yang disebut interaksi itu hanya face to face saja dan berlangsung secara spontan, tetapi yang dipentingkan adanya operant reinforcemen serta dasar yang paling utama dalam interaksi adanya prisip ekonomis yang selalu melihat adanya profit dan loss. Justru yang membuat kompleksnya struktur sosial itu dilihat, diukur, dari sejauh mana prinsip-prinsip itu tercermin dalam kehidupan (Ambo, 2010:182).

\section{B. METODE PENELITIAN}

Pendekatan penelitian yang digunakan dalam metode penelitian ini adalah pendekatan penelitian kualitatif. Pendekatan kualitatif dipilih karena metode penelitian kualitatif berguna untuk mengungkapkan bagaimana penjelasan mengenai strategi serta hambatan peer educator dalam memberikan edukasi mengenai HIV/AIDS. Maka pendekatan ini memungkinkan peneliti untuk lebihmemahami proses yang dilalui oleh peer educator dalam memberikan edukasi kepada pekerja seks perempuan mengenai HIV/ AIDS tersebut.

Sementara itu, tipe penelitian yang digunakan dalam penelitian ini adalah tipe penelitian deskriptif. Alasan peneliti menggunakan pendekatan kualitatif dan tipe deskriptif karna dapat mengungkapkan proses kejadian secara mendetail, sehingga dapat diketahui bagaimana strategi peer educator dalam memberikan edukasi mengenai kesehatan HIV/ AIDS terhadap pekerja seks perempuan. 


\section{Informan Penelitian}

Menurut Moleong (2004:132) bahwa informan adalah orang yang dimanfaatkan untuk memberikan informasi tentang situasi dan kondisi latar belakang penelitian, karena itu diharapkan informan adalah orang yang benarbenar paham dengan segala situasi dan kondisi penelitian dan menguasai masalah penelitian. Jadi, informan harus mempunyai banyak pengalaman tentang latar penelitian. Ia berkewajiban secara sukarela menjadi anggota tim penelitian walaupun hanya bersifat informal. Ia merupakan anggota tim yang dengan kebaikannya dan kesuka-relaannya ia dapat memberikan pandangan dari segi orang-dalam tentang nilai-nilai, sikap, bangunan, proses, dan kebudayaan yang menjadi latar penelitian tersebut.

Penelitian ini menggunakan teknik pemilihan informan dengan menggunakan teknik purposive sampling, yakni dengan cara mencari informan-informan yang sesuai dengan kriteria yang telah ditetapkan oleh penulis,

1. Adapun kriteria informan yang dipilih adalah Peer educator yang sebelumnya telah ditunjuk dan diberi pelatihan mengenai HIV/AIDS oleh PKBI, Peer educator yang sudah pernah mengajak pekerja seks melakukan tes VCT dan memberikan edukasi mengenai HIV/AIDS, serta Peer educator yang memiliki latar belakang sebagai pekerja seks perempuan, mantan pekerja seksperempuan, dan germo atau pemilik tempat penyedia layanan seksual.

\section{TEMUAN DAN PEMBAHASAN}

\section{Strategi Peer Educator dalam Peningkatan Kesadaran Pekerja Seks Perempuan terhadap Kesehatan Reproduksi}

Strategi merupakan suatu cara atau proses yang dilakukan oleh seseorang guna untuk mencapai suatu tujuan tertentu. Strategi juga diartikan sebagai upayaupaya atau tindakan-tindakan penyesuaian untuk mengadakan reaksi terhadap situasi lingkungan tertentu, dimana tindakan dilakukan secara sadar berdasarkan pertimbangan yang wajar. Program pencegahan HIV/AIDS untuk pekerja seks perempuan ini dapat dikatakan berhasil apabila pekerja seks perempuan yang diberi penyuluhan tesebut mau melakukan tes VCT. Penyuluhan akan diberikan oleh seorang peer educator yang merupakan populasi kunci dalam program ini. Peer educator dalam mengajak pekerja seks perempuan melakukan tes VCT tentunya memiliki rencana atau cara-cara yang dilakukan agar tujuannya berhasil dicapai. Berikut beberapa strategi peer educator dalam memberikan edukasi mengenai HIV/AIDS yang ditemui di lapangan:

\section{Penggunaan Sanksi}

Paksaan merupakan tindakan mengajak seseorang untuk berperilaku sesuai kehendak pihak yang berkuasa dengan menggunakan ancaman, imbalan, intimidasi atau bentuk lain dari tekanan atau kekuatan. Pihak yang berkuasa dalam hal ini adalah mucikari.

Mucikari atau germo adalah orang yang berperan sebagai pengasuh, perantara, atau pemilik pekerja seks komersial, karena adanya kepemilikian terhadap pekerja seks tersebut mereka memiliki otoritas untuk memaksakan kehendak mereka kepada pekerja seks tersebut. 
Untuk membuat para pekerja seks perempuan melakukan tes VCT, mucikari atau germo menggunakan kekuasaan yang dia miliki untuk memaksa pekerja seks perempuan agar mau melakukan tes tersebut. Jika mereka tidak mau melakukan tes diancaman akan diberhentikan kerja secara sepihak.

\section{Penggunaan Ganjaran Intrinsik}

Strategi lain yang dilakukan peer educator dalam memberikan edukasi mengenai HIV/AIDS yaitu dengan memberi pengarahan kepada pekerja seks tersebut. Pengarahan yang diberikan biasanya berupa nasihat. Penjangkauan yang dilakukan dengan memberi nasihat kepada pekerja seks perempuan biasanya dilakukan oleh mantan pekerja seks itu sendiri, mereka dianggap telah keluar dari zona tersebut. Sehingga nasihat mereka lebih didengarkan dibandingkan jika yang menasihati masih bekerja sebagai pekerja seks.

Nasihat yang diberikan peer educator seperti; nasihat pentingnya menjaga kesehatan alat reproduksi atau mengingatkan pekerja seks perempuan tersebut apakah akan selamanya menjadi pekerja seks, atau mengingatkan mereka akan pernikahan, karena jika mereka terkena HIV/AIDS kecil kemungkinan orang mau menikah dengan mereka mengingat HIV/AIDS merupakan penyakit yang mematikan.

Ganjaran intrinsik dilakukan juga dengan pendekatan persuasi. Pendidik ssebaya mengajak seseorang dengan cara memberikan alasan dan prospek baik yang meyakinkannya. Seseorang cenderung akan mengikuti ajakan orang lain jika, orang yang mengajak tersebut sudah melakukan sendiri tindakan tersebut, dan memberi dampak positif terhadapnya. Tindakan mengajak seseorang tidak selalu dilakukan sekali saja. Kadang kala, seseorang mau melakukan hal yang sama dengan kita setelah beberapa kali kita ajak. Demikian juga hal nya dengan mengajak seseorang melakukan tes untuk mengecek apakah seseorang positif HIV atau tidak.

Sebelum peer educator mengajak teman sebayanya melakukan tes VCT, ia telah terlebih dahulu melakukakannya. Kemudian, dia menceritakan kepada teman sebayanya manfaat yang ia rasakan dari melakukan tes VCT, serta manfaat pengetahuan mengenai HIV/AIDS. Kemudian ia akan memberikan edukasi mengenai HIV/AIDS tersebut kepada teman sebayanya, setelah itu baru lah peer educator mengajak pekerja seks perempuan melakukan tes VCT.

\section{Hambatan peer educator dalam memberikan edukasi mengenai HIV/AIDS untuk pekerja seks perempuan}

Penyuluhan yang dilakukan oleh peer educator tentunya tidak selalu berjalan sesuai dengan apa yang mereka inginkan. Terdapat beberapa faktor yang dapat menghalangi jalannya pemberian edukasi mengenai HIV/AIDS yang dilakukan peer educator terhadap pekerja seks perempuan tersebut. Faktor yang dapat menghambat jalannya penyuluhan tersebut dapat berasal dari dalam maupun dari luar diri peer educator. Berikut beberapa hal yang dapat menghambat peer educator dalam melakukan penyuluhan kepada pekerja seks perempuan berdasarkan fakta yang penulis temukan di lapangan: 
Pertukaran yang tidak seimbang antara peer educator dan pekerja seks perempuan

Teori pertukaran Homans bertumpu pada asumsi bahwa orang terlibat dalam perilaku untuk memperoleh ganjaran atau menghindari hukuman. Dalam proposisi Homans menyatakan bahwa bila seseorang berhasil memperoleh ganjaran dan menghindari hukuman, maka cenderung ia akan mengulangi tindakan tersebut. Namun jika ganjaran-ganjaran tidak seimbang atau tidak sesuai lagi dengan distribusi keadilan, maka kita akan berada dalam distribusi ketimpangan atau ketidak adilan dalam distribusi ganjaran.

Pertukaran yang tidak seimbang antara peer educator dengan pekerja seks perempuan menjadi penghambat dalam pelaksanaan program pencegahan HIV/AIDS ini. Penghargaan yang diterima peer educator jika berhasil mengajak pekerja seks melakukan tes VCT adalah mendapat uang transpor sebanyak Rp 70.000 per satu orang pekerja seks yang mau melakukan tes VCT. Sedangkan pekerja seks itu sendiri tidak mendapatkan apapun dengan melakukan tes tersebut. Pekerja seks hanya dijadikan objek agar program yang dilaksanakan PKBI ini dapat mencapai target pencapaian yang telah ditetapkan oleh Global Fund selaku founding dari program ini. Dana yang disalurkan Global Fund tergantung target yang mereka tetapkan, sehingga PKBI harus memenuhi target tersebut.

Adanya ketimpangan atau ketidakadilan dalam distribusi ganjaran tersebut membuat pekerja seks menunda melakukan tes VCT, bahkan beberapa dari mereka tidak mau melakukan tes tersebut, atau mereka melakukan tes VCT hanya karena unsur keterpaksaan. Hal ini dikarenakan mereka menganggap tes tersebut hanya membuang waktu mereka, lebih baik mereka melayani pelanggan mereka terlebih dahulu.

Ketidakpercayaan Pekerja Seks Perempuan terhadap Peer Educator

Menurut teori pertukaran, pertukaran sosial tidak hanya diukur dengan nilai uang, sebab dalam berbagai transaksi sosial dipertukarkan juga hal yang nyata dan tidak nyata. Ganjaran yang diterima seseorang tidak hanya ganjaran ekstrinsik namun juga ganjaran intrinsik seperti kepercayaan. Dalam pandangan sosiologi, kepercayaan menunjuk pada hubungan antara dua belah pihak atau lebih yang mengandung harapan yang menguntungkan salah satu atau kedua belah pihak melalui interaksi sosial. Dalam konsep sosiologi kepercayaan dikenal dengan trust. Kepercayaan tidak muncul dengan sendirinya tapi, terbit dari proses hubungan antar pribadi dari aktor-aktor yang terlibat.

Ganjaran intrinsik berupa kepercayaan ini bisa menjadi faktor suksesnya pelaksanaan program pencegahan HIV/AIDS untuk pekerja seks perempuan ini. Namun hal sebaliknya bisa terjadi jika pekerja seks perempuan tidak mempercayai peer educator yang telah memberikan edukasi kepadanya Ketidakpercayaan pekerja seks perempuan terhadap peer educator timbul karena pekerja seks perempuan merasa apa yang disampaikan peer educator belum sepenuhnya ia terapkan untuk dirinya sendiri. Seperti halnya dalam menjaga kesehatan alat reproduksi, peer educator mengetahui bahaya dari HIV/AIDS maupun penyakit menular seks, namun mereka tetap saja bekerja sebagai pekerja seks, yang rentan terkena HIV/AIDS. Hal ini membuat pekerja seks tidak yakin dengan apa yang di sampaikan oleh peer educator. 
Selain itu, ketidakpercayaan terhadap peer educator juga dikarenakan faktor umur, beberapa pekerja seks menganggap dirinya lebih paham mengenai HIV/AIDS dibandingkan peer educator. Pekerja seks merasa lebih memahami masalah kesehatan reproduksi karena dia sudah lebih berpengalaman dibandingkan peer educator nya yang belum lama menjadi pekerja seks. Sehingga berbekal pengalaman yang ia miliki ia bisa menjaga kesehatan reproduksinya yang sejauh ini masih baik-baik saja meskipun melakukan hubungan seks berisiko.

Adanya ketidakpercayaan terhadap peer educator menimbulkan kesulitan dalam mengajak pekerja seks melakukan tes VCT, sehingga peer educator membutuhkan waktu yang cukup lama dan pemberian edukasi yang berulangulang sehingga pekerja seks mau melakukan tes VCT. Ketidakpercayaan ini biasanya muncul jika peer educator berasal dari pekerja seks perempuan yang masih aktif, mereka dianggap belum bisa sepenuhnya menerapkan apa yang mereka sampaikan.

\section{KESIMPULAN}

Untuk membangun kesadaran akan pentingnya menjaga kesehatan seksual para PSK, seks educator sebaya menerapkan strategi pemberian sanski baik sanksi ekstrinsik dan intrinsik. Sansksi ekstrinsik digunakan oleh mucikari, sedangkan sanski intrinsik digunakan oleh aktivis. Penelitian lain diperlukan untuk mempelajari dampak dari penggunaan strategi pendidikan kesehatan reprosukdi dengan pendkestan ganjaran yang berbeda terhadap perilaku kesehatan reproduksi PSK.

\section{E. UCAPAN TERIMAKASIH}

Penulis mengucapkan terimakasih kepada seluruh informan yang telah bersedia mengalokasikan waktunya selama proses penelitian. Penulis juga mengucapkan ribuan terimakasih kepada para dosen pembimbing yang telah mengarahkan dan menjadi mentor selama pelaksanaan penelitian ini.

\section{DAFTAR PUSTAKA}

\section{Buku:}

Afiyanti, Yati., Anggi Pratiwi. 2016. Seksualitas dan Kesehatan Reproduksi Perempuan. Jakarta: Raja Grifindo Persada.

Afrizal, 2014. Metode Penelitian Kualitatif: Suatu Upaya Mendukung Penggunaan Penelitian Kualitatif dalam Berbagai Disiplin Ilmu, Jakarta: Raja Grifindo Persada

Lestari, Tri Wiji., Elisa Ulfiana.,Suparmi. 2015.Kesehatan Reproduksi. Jakarta: Buku Kedokteran EGC.

Moleong, Lexy J. 2004. Metodologi Penelitian Kualitatif. Bandung:Penerbit Rosda.

Noviana Nana.2013. Kesehatan Reproduksi HIV/AIDS. Jakarta: CV. Trans Infi Media.

Poloma, Margaret. 1994. Sosiologi Kontemporer. Jakarta: Raja Grifindo Persada.

Raho, Bernard. 2007. Terori Sosiologi Modren. Jakarta 
Ritzer, George., Douglas J. Goodman, 2004. Teori Sosiologi Modern. Jakarta: Kencana.

Simajuntak, B Pengantar Kriminologi dan Patologi Sosial . Tarsito, Bandung. 1982.

Soekanto, Soejono. 2002. Sosiologi Suatu Pengantar. Jakarta : RajaGrafindo Persada

Susanto, Astrid. 1979. Pengantar Sosiologi dan Perubahan Sosial. Jakarta: Binacipta.

Suyanto, Bagong. 2013. Masalah Sosial Anak. Jakarta: Prenadamedia Group.

Upe, Ambo. 2010. Tradisi Aliran dalam Sosiologi. Jakarta: Rajawali Pres.

Yatim, D.I. Dialog Seputar AIDS. Jakarta: PT. Gramedia Widiasarana Indonesia)

\section{Skripsi/Tesis}

Benita, Nyndia Rena. 2012. Pengaruh Penyuluhan terhadap Tingkat Pengetahuan Reproduksi pada Remaja Siswa SMP Kristen Gergaji: Skripsi $\quad$ Fakultas Kedokteran Universitas Diponegoro.

Lasyera, Humaira (2018) Peranan Anggota Legislatif dalam Menanggulangi Pekerja Seks Komersial (PSK) di Kota Padang. Skripsi Jurusan Ilmu Politik Universitas Andalas.

Sri Wahyuni, Uci. 2017. Pengaruh Metode Peer Educator tentang Mestrual Hygiene terhadap Perilaku pada Siswi MTSn 1 Payakumbuh: Skripsi Fakultas Keperawatan Universitas Andalas.

Utama, Candra. 2002. "Advokasi Kesehatan Reproduksi". Skripsi Jurusan Sosiologi Universitas Andalas.

\section{Jurnal Penelitian}

Andayani.L,S. (2005). Pengaruh Peer Edocator terhadap Pengetahuan dan Sikap Mahasiswa Universitas Sumatera Utara dalam hal HIV/AIDS. Universitas Sumatera Utara.

Aprila,F (2014) Efektivitas Metode Pendidikan Massa dengan Metode Peer Eucation terhadap Pengetahuan dan Sikap siswi SMA tentang Pemeriksaan Payudara Sendiri (SADARI) di SMAN 1 dan SMAN 10 Padang. Universitas Andalas.

Ardila, Juli (2016) Upaya Penanggulangan Prostitusi. Universitas Negeri Lampung

Harahap, Juliandi., Lita Sri Andayani. Pengaruh Peer Educator terhadap Pengetahuan dan Sikap Mahasiswa dalam Menanggulangi HIV/AIDS di Universitas Sumatera Utara. Fakultas Kesehatan Masyarakat Universitas Sumatera Utara.

Purwani, Yanik. Pengaruh Peer Edukataor terhadap Peningkatan dan Sikap tentang HIV/AIDS.

Sriasih., dkk. Pengaruh Pendidikan Seksual Remaja oleh Pendidik Sebaya terhadap Pengetahuan dan Sikap Remaja terhadap Bahaya Seks Bebas. 


\section{Internet}

BKKBN. 2008 Remaja dan SPN (Seks Pranikah) 15 November 2018

https:/ / berpacaransehat.wordpress.com/tag/international-conference-onpopulation-and-development/ diakses 15 November 2018

https:/ / dewasastra.wordpress.com/2012/03/12/ pekerja-seks-komersial-psk/ diakses 12 Desember 2018

https://en.m.wikipedia.org/wiki/International_Conference_on_Population_and_D evelopment diakses pada 15 November 2018

http://keuanganlsm.com/united-nations-population-fun-unfa/ diakses pada 20 januari 2019

http:/ / m.francesco-toldo.nomor.net/id4/1231-1114/Unfpa_12614_m-francescotoldo-ayam.html pada 20 januari 2019

https:/ / m.gosumbar.com/berita/baca/2018/12/27/ data-hivaids-di-sumbarmengejutkan-pemprov-siapkan-payung-hukum-berantas-lgbt diakses pada 20 juli 2019

https:/ / portal-ilmu.com/apa-itu-bimbingan-konseling/ diakses 20 Januari 2019

http:/ / www.depkes.go.id/article/print/15090200001/situasi-kesehatanreproduksi-remaja.html diakases 15 November 2018

http://www.kebijakanaidsindonesia.net/id/artikel/artikel-tematik/212-kejelasanperan-komisi-penanggulangan-aids-dalam-perda-propinsi-penanggulanganaids diakses pada 20 januari 2019

https:/ / www.researchgate.net/publication320998624 diakses pada 5 Februari 2019 https:/ / www.scribd.com/doc/45029703/konselor-sebaya diakses 3 Desember 2018 